\title{
Pengujian Aplikasi Simulator Air Tanah Permukaan dengan Memanfaatkan Teknologi Kinect dan Maket
}

\author{
Fachrim Irhamnah Rachman*1, Titin wahyuni ${ }^{2}$ \\ 1,2Universitas Muhammadiyah Makassar \\ e-mail: Fachrim@unismuh.ac.id *
}

\begin{abstract}
This study aims to test the application of surface ground water simulators using the DEM (Digital Elevation Model) of the mockups made using the IR Depth sensor of the kinect camera. This research is a system design in the form of modeling which begins with the formulation of the problem, library research and experimental research by developing by developing the use of IR depth sensor kinect camera in measuring the height of the image pixels by calculating the difference in pixel depth and the base of the mockup and then the mockup is simulated in a simulated way. real and compared to the DEM mockup tests performed on the simulator application. The results of this study indicate the extent of the comparison of the performance of the simulator with the real simulation of the model
\end{abstract}

Keyword: simulator; DEM; Depth; kinect; maket

\begin{abstract}
Abstrak
Penelitian ini bertujuan untuk menguji aplikasi simulator air tanah permukaan dengan menggunakan DEM (Digital Elevation Model) dari maket yang dibuat dengan memanfaatkan sensor IR Depth camera kinect. Penelitian ini merupakan perancangan sistem dalam bentuk pemodelan yang diawali dengan perumusan masalah, studi kepustakaan dan penelitian ekperimental dengan mengembangkan dengan mengembangkan penggunaan sensor IR depth camera kinect dalam mengukur ketinggian pixel-pixel gambar dengan menghitung selisih kedalaman pixel dan dasar maket untuk kemudian maket tersebut disimulasikan secara nyata dan dibandingkan dengan pengujian DEM maket yang dilakukan pada aplikasi simulator. Hasil penelitian ini menunjukkan sejauh mana perbandingan kinerja simulator dengan simulasi nyata dari maket.
\end{abstract}

Kata kunci: simulator; DEM; Depth; kinect; maket

\section{Pendahuluan}

Simulator air tanah permukaan adalah penelitian yang telah banyak dilakukan di waktu lalu. Penelitian ini merupakan penelitian yang sangat bermanfaat khususnya dalam informasi dan visualisasi genangan banjir yang akan terjadi di daerah-daerah peneletian tertentu. Dengan memafaatkan Digital Elevation Model (DEM) dan algoritma tertentu yang diterapkan di dalam simulasi sendiri.

Adapun dari seluruh penelitian yang telah dilakukan ditemukan sebuah masalah yakni tidak adanya alat uji. Ini disebabkan karena untuk menguji kita harus turun langsung ke lapangan guna mengukur seluruh tinggi permukaan secara real. Hal ini sangat sulit untuk dilakukan, maka untuk mempermudah pengujian dibutuhkan maket dan alat uji lainnya yang lebih efektif dan efisien. Dari sinilah penelitian selanjutnya yakni membuat sebuah evaluator atau alat uji dari simulator air tanah permukaan, menggunakan media maket dan sensor kedalaman kinect.

\section{Metode Penelitian}

Beberapa penelitian yang mengenai banjir dan air tanah permukaan telah dilakukan sebelumnya. Penelitian mengenai simulasi banjir telah dilakukan sebelumnya yakni simulasi arah aliran air permukaan menggunakan algoritma Deep First Search dengan sumber hujan multipoint [1], simulasi aliran permukaan dengan kecepatan aliran air menggunakan persamaan bernoulli [2], simulasi aliran air dan menvisualisasikan progres terjadinya banjir sehingga 
diketahui luasan genangan air berdasarkan arah aliran air permukaan menggunakan algoritma Multiple Flow Direction (MD8) dan Deep First Search dengan sumber hujan multipoint dan kecepatan aliran air menggunakan persamaan Bernoulli dengan konsep Celluler Automata untuk menentukan arah aliran air [3], sehingga dapat dilakukan antisipasi terhadap bencana banjir. Bagaimana membuat sistem yang dapat mensimulasikan aliran air dan menvisualisasikan progres terjadinya genangan air pada daerah rawan banjir berdasarkan sumber air multipoint dengan arah aliran air dari data Digital Elevation Model (DEM) dengan metode algoritma Multiple Flow Direction (MD8) dan Deep First Search [4].

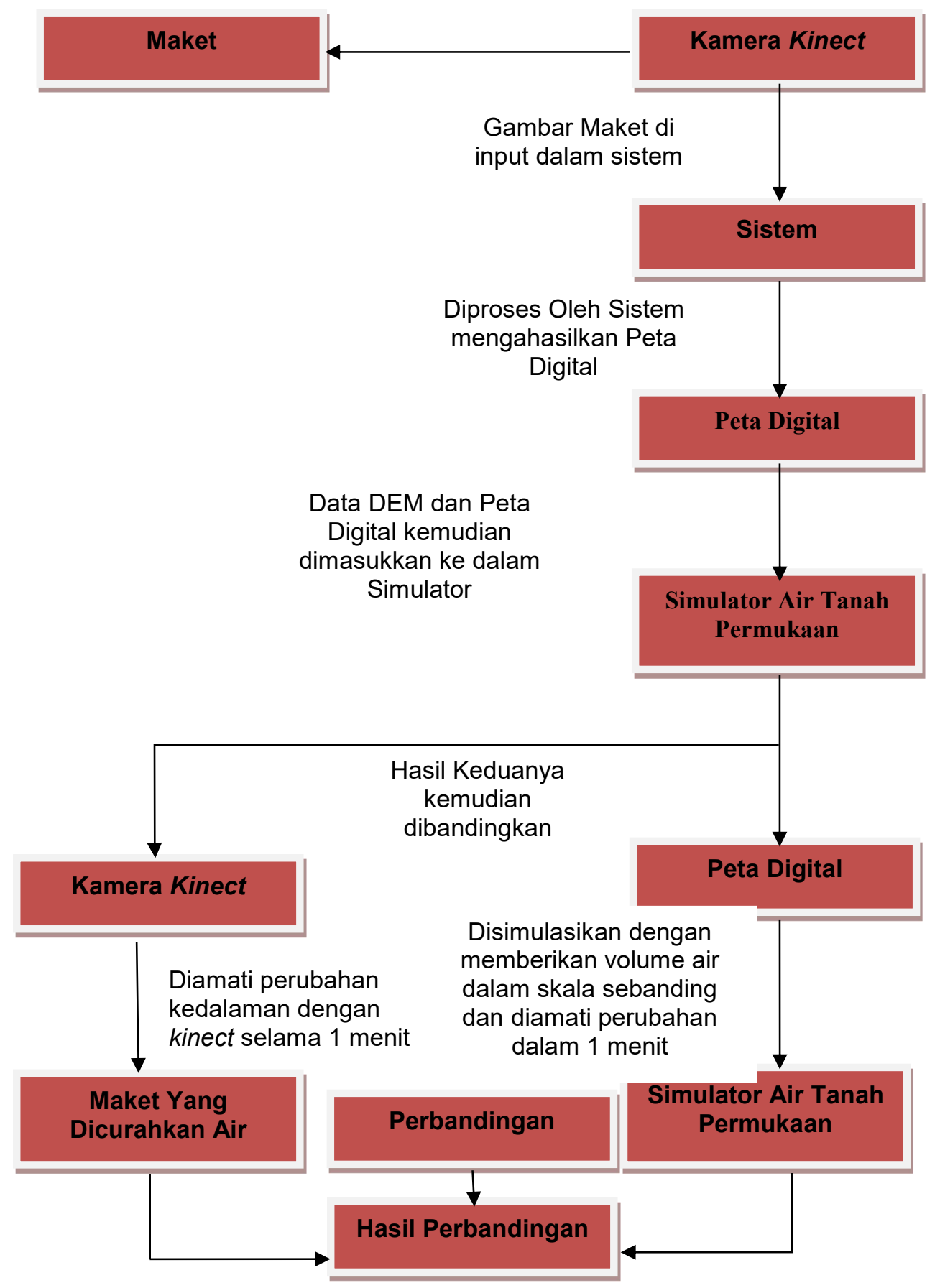

Gambar 1. Gambaran Umum Sistem 
Dari gambar umum sistem di atas ada 2 bagian besar yakni membuat DEM dari maket dan menguji dengan membandingkan hasil dari simulasi maket dan simulasi aplikasi. Gambar 2 menunjukkan ilustrasi DEM menggunakan maket. Maket ini sebagai representasi dari sebuah daerah yang akan divisualisasikan ke dalam bentuk digital map. Maket ini akan dibentuk sedemikian rupa termasuk tinggi rendah permukaan daerah tersebut.

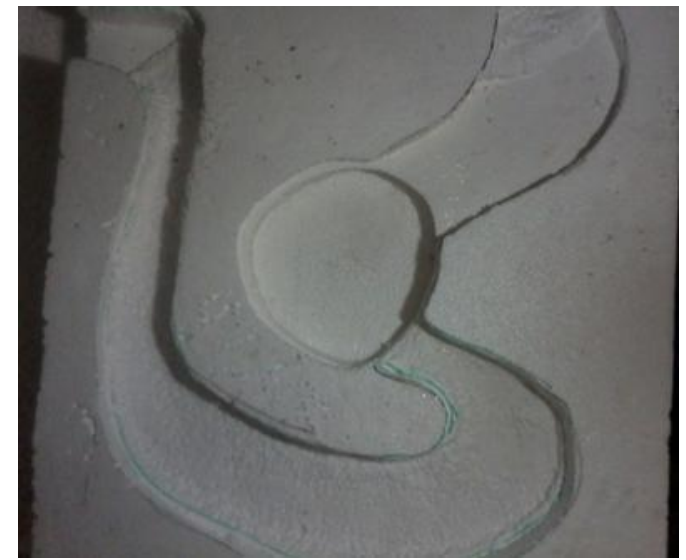

Gambar 2. Ilustrasi Maket

Kinect dengan depth sensor akan mengambil gambar dari maket tersebut. Setelah itu, proses yang akan terjadi yakni setiap pixel dari gambar yang telah diambil memiliki jarak kedalaman dari kamera kinect pada saat gambar terambil. Jarak ini dibangkitkan dengan algoritma yang dibuat dalam program memanfaatkan sensor inframerah depth sensor dari kinect terhadap permukaan maket dari jarak $90 \mathrm{~cm}$. Proses pengambilan gambar maket oleh kinect ditunjukkan pada gambar 3 .

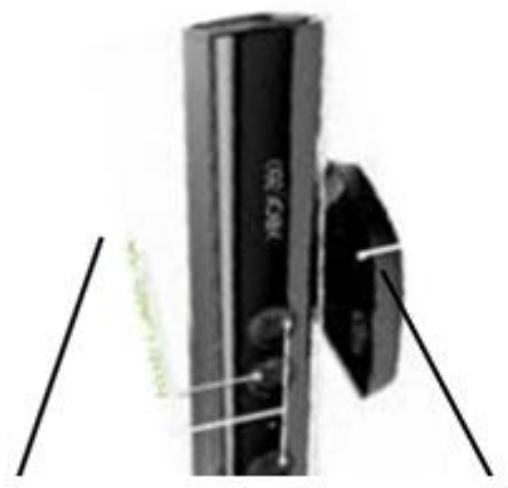

\section{Kinect Mengambil gambar}

maket
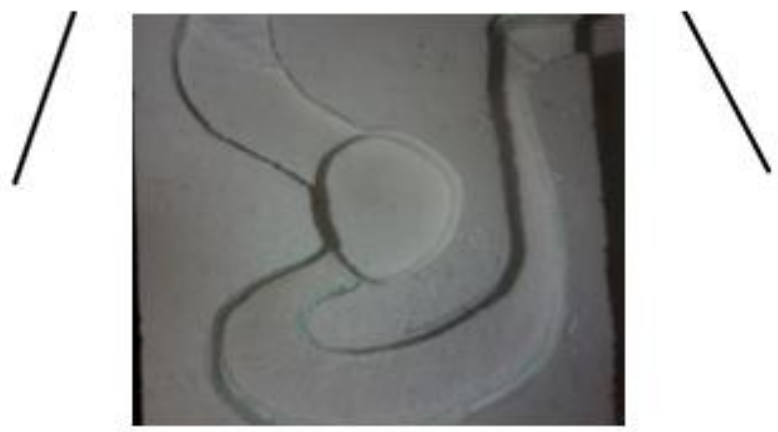

Gambar 3. Pengambilan Gambar Maket oleh Kinect 


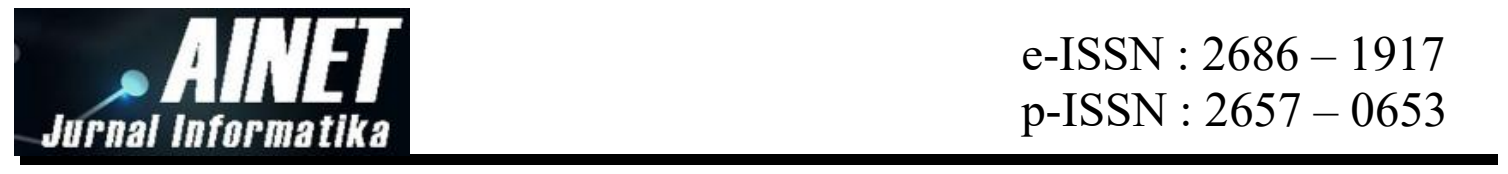

Proses yang akan terjadi selanjutnya yakni setiap pixel dari gambar yang telah diambil memiliki jarak kedalaman dari kamera kinect pada saat gambar terambil. Jarak ini dibangkitkan dengan algoritma yang dibuat dalam program memanfaatkan sensor inframerah depth sensor dari kinect terhadap permukaan maket dari jarak $90 \mathrm{~cm}$.

Jarak-jarak pixel tersebut kemudian diproses oleh aplikasi dan datanya disimpan dalam output file teks yang sesuai format dari data inputan aplikasi aliran air tanah permukaan dan display akan menunjukkan hasil berupa angka deretan baris dan angka. Tabel kedalaman pixel dari gambar maket ditunjukkan pada tabel 1 berikut. Pada tabel 1 , satuan yang digunakan berupa satuan millimeter.

Tabel 1. Kedalaman Pixel dari Gambar Maket

\begin{tabular}{llllllllll}
\hline 216 & 215 & 214 & 214 & 214 & 214 & 216 & 220 & 223 & 225 \\
216 & 215 & 220 & 220 & 220 & 220 & 215 & 220 & 220 & 220 \\
220 & 200 & 220 & 220 & 220 & 220 & 210 & 220 & 220 & 220 \\
220 & 220 & 215 & 220 & 220 & 220 & 200 & 220 & 220 & 220 \\
220 & 220 & 115 & 100 & 100 & 115 & 220 & 220 & 220 & 220 \\
220 & 220 & 113 & 100 & 100 & 220 & 220 & 220 & 220 & 220 \\
115 & 115 & 115 & 100 & 100 & 220 & 220 & 220 & 220 & 220 \\
200 & 200 & 200 & 200 & 200 & 220 & 200 & 200 & 200 & 200 \\
\hline
\end{tabular}

Angka-angka pada tabel 1 dibangkitkan oleh depth sensor kinect. Setelah angka-angka tersebut dibangkitkan, maka ketinggian permukaan maket dengan diperoleh dengan cara menghitung selisih antara jarak maket dari kinect dengan tinggi kedalaman pixel. Maka dihasilkanlah tinggi permukaan pixel maket. Setelah itu data gambar dan jarak tersebut akan dikonversi ke dalam file yang dibutuhkan dalam aplikasi simulator tanah permukaan dan kemudian akan dieksekusi oleh aplikasi simulasi air tanah permukaan. Hasil eksekusi tersebut akan dijadikan bahan evaluasi untuk pengembangan aplikasi simulasi berikutnya. Setelah itu maket kemudian diberikan curahan air dengan volume tertentu, yang akan kemudian disorot oleh kinect untuk diamati perubahan kedalaman pada permukaan maket tersebut. Hal yang sama dilakukan pada peta digital DEM yang dihasilkan tadi. Akan dilakukan simulasi dengan curahan air dalam skala sebanding dalam jangka waktu 1 menit untuk di amati perubahan kedalaman dan kinerja simulasi tersebut. Hasil kedua simulasi tersebut kemudian dibandingkan untuk melihat sejauh mana akurasi kinerja aplikasi simulator air tanah permukaan.

\section{Hasil dan diskusi}

Gambar 4 menunjukkan hasil dari simulasi maket yang dijalankan. Terlihat pada gambar bahwa terjadi perubahan ketinggian dan perubahan warna. Gambar memperlihatkan secara menyeluruh aliran air dan genangan air juga perubahan ketinggian yang terlihat dari warna. Air dialirkan dari titik paling tinggi jalur aliran air pada maket, yakni dari sudut kanan atas pada masing-masing gambar. Proses tampak pada gambar perubahan warna, ini menandakan adanya perubahan ketinggian akibat aliran air.

Dipanel akhir gambar pun terlihat wana biru sudah ditutupi oleh warna merah. Ini menandakan air mengalir dan telah memenuhi aliran air pada maket, dengan ini menandakan terjadinya perubahan ketigggian pula. 


\begin{tabular}{ll} 
Jurnal informatika & e-ISSN : $2686-1917$ \\
Jithe & p-ISSN : $2657-0653$ \\
\hline
\end{tabular}

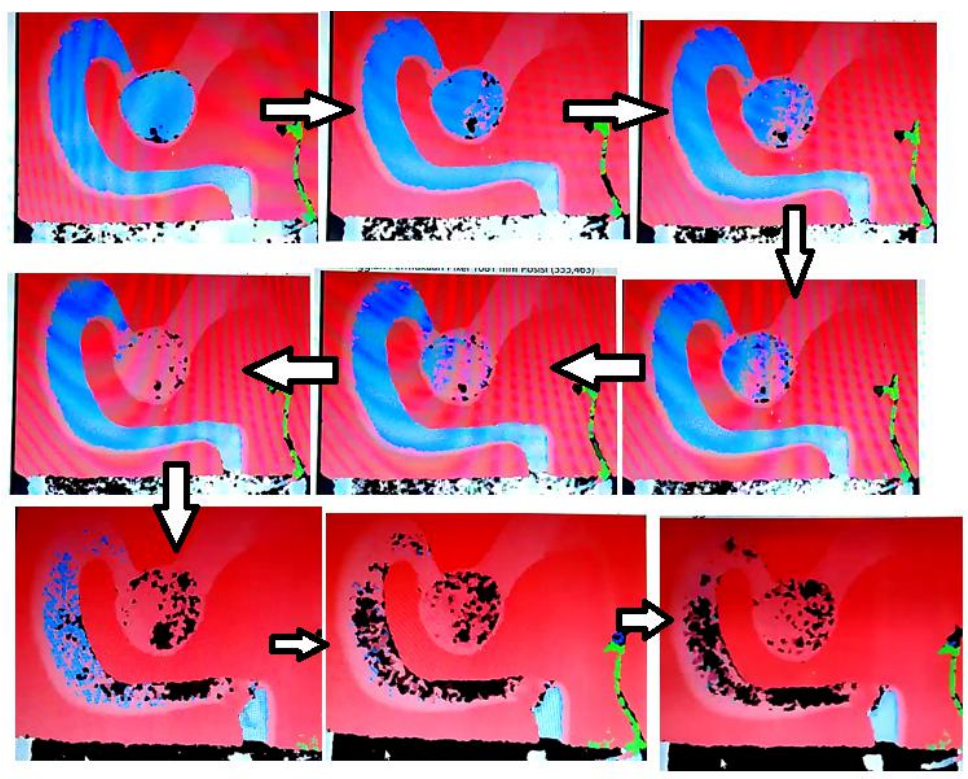

Gambar 4. DEM Maket setelah Disimulasikan dengan Air

Keterangan untuk setiap warna yang terdapat pada gambar 4 dijelaskan pada tabel 2 berikut ini.

Tabel 2. Keterangan Warna DEM Maket

\begin{tabular}{cccc}
\hline No. & Nila Kedalaman & Warna & Intensitas \\
\hline 1 & $<800$ & Hitam & 0 \\
2 & $800-850$ & Biru & Nilai kedalaman \\
3 & $850-900$ & Hijau & Nilai kedalaman \\
4 & $900-1000$ & Merah & Nilai kedalaman \\
5 & $>1000$ & Hitam & 0 \\
\hline
\end{tabular}

Dari tabel 2 terlihat bahwa ketika kedalaman $<800$ maka DEM maket berwa

rna hitam dengan nilai intensitas 0 . Ketika kedalaman berada di antara 800 hingga 850 maka terjadi perubahan warna yaitu biru dengan intensitas sesuai kedalaman. Ketika kedalaman berada di antara 850 hingga 900 maka DEM maket berwarna hijau dengan intensitas sesuai dengan kedalaman. Ketika kedalaman berada di antara 900 hingga 1000 maka warna DEM maket adalah merah. Ketika DEM maket berada pada kedalaman di atas 1000 maka akan berubah warna dan kembali ke warna hitam dengan intensitas 0 .

Pengujian DEM pada aplikasi simulasi dilakukan dengan cara menjalankan simulasi dari berbagai titik hujan dan melihat perubahan ketinggian dari pola aliran air yang diuji yakni 3 aplikasi simulasi dan kemudian dibandingkan dengan simulasi maket sebelumnya. 


$\begin{array}{ll}\text { Jurnal Informatika } & \text { e-ISSN : } 2686-1917 \\ \text { s } & \text { p-ISSN : } 2657-0653\end{array}$

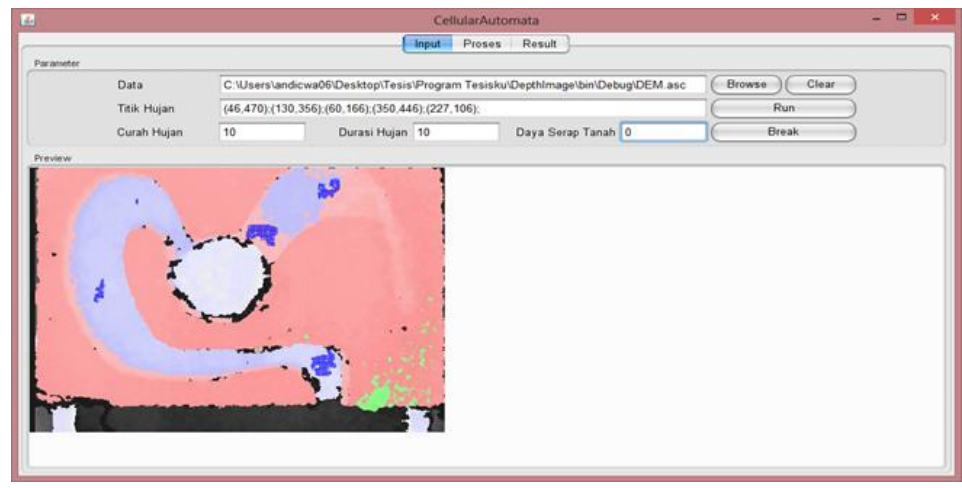

Gambar 5. Simulasi pada Aplikasi Pertama

Gambar 5 menunjukkan pengujian aplikasi dari Masna Wati yakni simulasi aliran permukaan dengan kecepatan alir menggunakan persamaan Bernoulli. Warna biru pada posisi aliran air pada gambar adalah aliran air. Gambar menunjukkan bahwa hasil belum sesuai dengan simulasi nyata yang dilakukan pada maket sebelumnya.

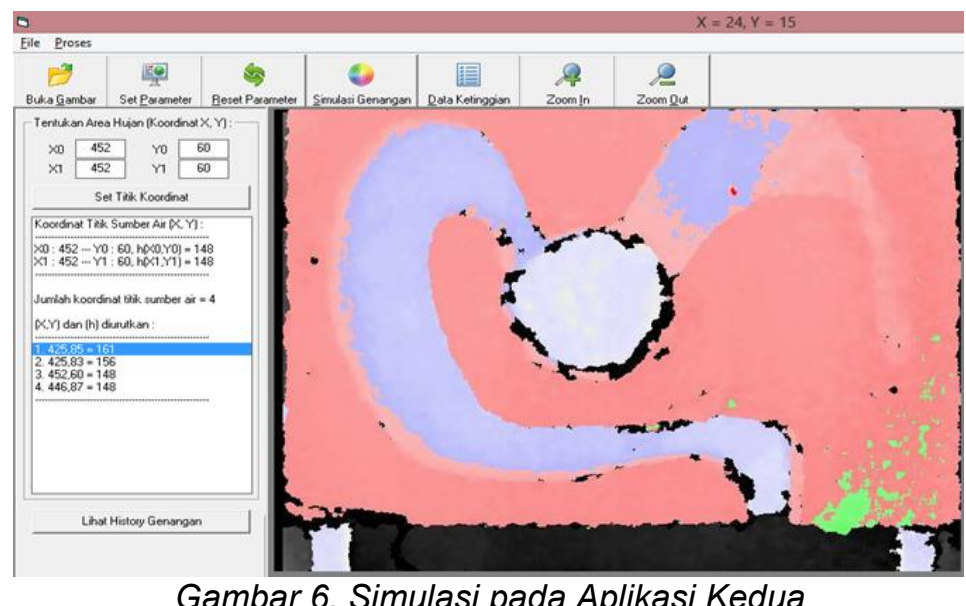

Gambar 6. Simulasi pada Aplikasi Kedua

Gambar 6 menunjukkan simulasi aplikasi kedua yakni pengujian pada aplikasi Tommy Yesaya. Pengujian yang dilakukan pada simulasi ini adalah simulasi arah aliran air permukaan menggunakan algoritma Depth First Search dengan sumber hujan Multipoint. Warna merah kecil di atas adalah titik aliran air. Simulasi ini tidak sesuai dengan simulasi yang dilakukan pada maket sebelumnya.




Gambar 7 menunjukkan hasil pengujian pada aplikasi ketiga yakni pengujian pada aplikasi Mohamad Arif Suryawan. Pengujian sistem menggunakan simulasi genangan air untuk antisipasi peringatan dini bencana banjir. Warna merah kecil di atas adalah titik aliran air. Hal ini tidak sesuai dengan simulasi yang dilakukan pada maket sebelumnya.

Dari pengujian aplikasi dan perbandingan dengan simulasi maket, maka dapat dinilai bahwa untuk penerapan aplikasi dikehidupan nyata belum real atau masih harus dikembangkan lebih ke depannya. Hal ini terjadi karena belum sesuai dengan fakta yang berjalan pada simulasi maket

\section{Kesimpulan}

Berdasarkan data yang telah diperoleh dari analisa hasil penelitian, maka dapat diambil kesimpulan bahwa sensor kedalaman kinect yang menggunakan IR dapat dimanfaatkan untuk membuat DEM (Digital Elevation Model). Dengan menggunakan maket sebagai modelnya. Sensor kedalsman kinect juga dapat digunakan untuk menguji aplikasi simulator sendiri. Tingkat akurasi kinect sendiri dalam mengukur jarak dan ketinggian bermacam-macam bergantung pada jarak kinect dengan object itu sendiri. Semakin jauh jaraknya, maka semakin lemah atau kurang pula akurasinya.

Aplikasi simulator ini masih memiliki banyak sisi untuk dikembangkan terutama dari sisi inputan parameter. Karena melalui pengujian pengamatan langsung dengan membandingkan antara kenyataan lapangan dan hasil dari 3 aplikasi simulasi didapatkan perbedaan yang signifikan. Di mana aplikasi simulasi berjalan tidak sesuai dengan apa yang ada pada simulasi fisik maket.

\section{Referensi}

[1] Y. T. Paulus, "SIMULASI ARAH ALIRAN AIR PERMUKAAN MENGGUNAKAN ALGORITMA DEPTH FIRST SEARCH DENGAN SUMBER HUJAN MULTIPOINT," 2012.

[2] M. WATI, "Simulasi Aliran Permukaan dengan Parameter Kecepatan Alir Menggunakan Persamaan Bernoulli," Makassar Univ. Hasanuddin, 2012.

[3] N. Rasyid and Z. Zainuddin, "Simulasi Aliran dan Distribusi Air Permukaan Menggunakan Model Elevasi Digital dan Cellular Automata dengan Memperhitungkan Volume dan Daya Serap," 2011.

[4] M. A. Suryawan and E. M. Hasiri, "PENERAPAN ALGORITMA MULTIPLE FLOW DIRECTION UNTUK PEMODELAN GENANGAN BANJIR," Semin. Nas. APTIKOM, pp. 67-70, 2017. 